\title{
SYNTHESIS AND CYCLIZATION OF SOME THIOSEMICARBAZIDE DERIVATIVES
}

\author{
${ }^{1}$ Hamed Y. Moustafa*, ${ }^{1}$ Mohammed A. Younis, ${ }^{2}$ Mohammed M. Azab, \\ ${ }^{1}$ Mohammed I. Khalil
}

${ }^{1}$ Department of Chemistry, Faculty of Science, Zagazig University, Zagazig, Egypt

${ }^{2}$ Department of Chemistry, Faculty of Science, Banha Universty, Banha, Egypt E-mail: $\underline{\text { mohmed.505@yahoo.com }}$

\begin{abstract}
The thiosemicarbazide $\mathbf{3}$ was obtained from reaction between hydrazine $\mathbf{2}$ and heteroallene $\mathbf{1}$. The condensed triazotriazole derivative $\mathbf{5}$ was obtained from the reaction of compound $\mathbf{3}$ with diethyl malonate. The cyclization of thiourea unit of compound $\mathbf{3}$ by heteroallene $\mathbf{1}$ furnished triazine 8. Benzoylation of compound $\mathbf{3}$ using benzoyl chloride $\mathbf{9}$ formed triazole derivative 11. Reaction of compound 3 and maleic anhydride $\mathbf{1 2}$ gave furothiadiazine 13. cyclohexanopyrimidinthione $\mathbf{1 6}$ was obtained as a result of cyclocondensation of cyclohexanone $\mathbf{1 4}$ with compound $\mathbf{3}$. Triazole 19 obtained from compound $\mathbf{3}$ and ammonium isothiocyanate $\mathbf{1 7}$ under thermal condition. Reaction of compound $\mathbf{3}$ with ethyl bromoacetate gave thiazole derivative 22. [2+3] cyclocondensation of acetyl acetone $\mathbf{2 3}$ and compound $\mathbf{3}$ provided pyrazole $\mathbf{2 5}$. Triazolotriazole 27 obtained from Formalin 26 and compound 3. Compound 3 suffers intramolecular base mediated cyclization affording triazole 28. Keeping compound $\mathbf{3}$ and propinaldehyde $\mathbf{2 9}$ under reflux provided triazolotriazole 31. Compound 3 oxidized by iodine to oxadiazole 32. Acylation of compound 3 by succinic acid formed triazolthione 34 .
\end{abstract}

Key words: Hydrazine derivatives, Thiosemicarbazide, Azoles, Azines

\section{Introduction}

Thiosemicarbazides possessing both electro- and nucleophilic reactivity can serve as versatile building blocks and have been extensively used in various carbon - carbons, carbon - heteroatom bond forming reactions using simple available laboratory reagents [Greenbaum et al., 2004], [Sanack et al., 2007], [Nogachi et al., 2003], [Foroumadi et al., 2003], [Dobosz et al., 1995/1996] and [Karakus and Rollas, 2002]. Some 
azoles and azines as important fine chemicals [Bamsal and Bhagchandani, 1982], [Ghoneim and Assy, 2015] and [Avanzo et al., 2012] have been frequently found in many natural product and drugs and have exhibited a wide range of biological activities, such as antibacterial [Bayrak et al., 2009], anticancer [Chimenti et al., 2007], antiinflammatory properties [Tozkoparan $\boldsymbol{e t}$ al., 2002].

\section{Results and discussion}

The thiosemicarbazide 3 was obtained from the attack of nucleophilic nitrogen of hydrazine $\mathbf{2}$ to the electrophilic carbon of heteroallene function of compound 1 (Scheme 1).

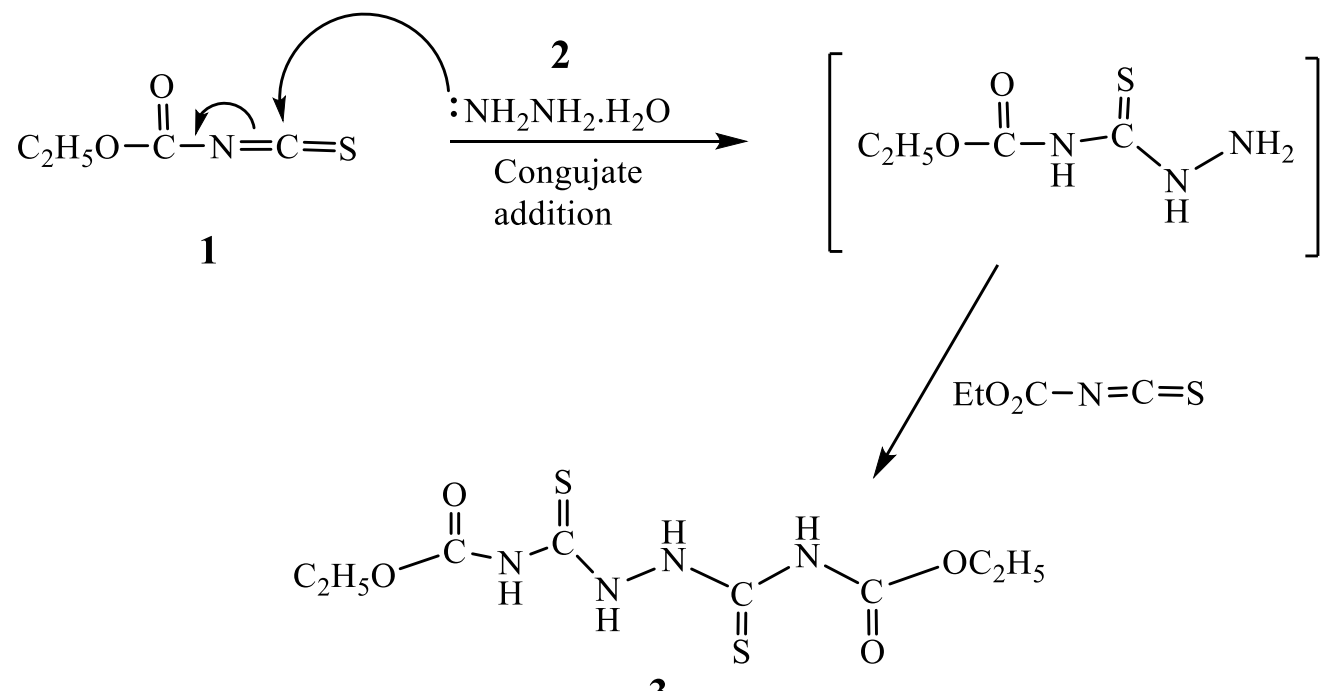

3

Scheme 1

The structure of thiosemicarbazide $\mathbf{3}$ was substantiated from its spectral and analytical data. Its IR spectrum displayed $\mathrm{NH}, \mathrm{C}=\mathrm{O}$ and $\mathrm{C}=\mathrm{S}$ groups. Further support for the assigned structure was gained from its ${ }^{1} \mathrm{H}$ NMR spectrum that showed signals for $\mathrm{NH}, \mathrm{CH}_{3}$, and $\mathrm{CH}_{2}$, also from mass spectrum showed a peak at $\mathrm{m} / \mathrm{z} 294.34\left(\mathrm{M}^{+}, 68.67 \%\right)$ cross- ponding to its molecular ion with a base peak at $\mathrm{m} / \mathrm{z} 157.25$ (100\%).

The condensed Triazolotriazole derivative $\mathbf{5}$ was obtained as the result of base mediated acylation of more acidic nitrogen using diethyl malonate $\mathbf{4}$ as acylating agent followed by intramolecular cyclodehydration and subsequent hydrolysis and decaroxylation of less stable ester group (Scheme 2). 
<smiles>CCOC(=O)CC(=O)N(C(=O)CC)C(=S)NNC(=S)N(C(=O)CC(=O)OCC)C(=O)CC(=O)OCC</smiles><smiles>CCOC(=O)CCC(C)CC(=O)N(C(=O)CC)C(=S)NNC(=S)N(C(=O)CC)C(=O)CC(=O)OCC</smiles><smiles>CCOC(=O)C=C1NC(=S)n2c(=S)[nH]c(=O)n21</smiles>

Scheme 2

The structure assigned to the condensed system 5 was agreement with analytical and spectral data, thus IR spectrum shows NH group at 3140 $\mathrm{cm}^{-1}$ as medium band, carbonyl absorption frequency was detected at v1711 $\mathrm{cm}^{-1}$ as sharp strong band, $\mathrm{C}=\mathrm{C}$ was located at $1581 \mathrm{~cm}^{-1}$ in addition to $\mathrm{C}=\mathrm{S}$ at that showed frequency at $1235 \mathrm{~cm}^{1} .{ }^{1} \mathrm{H}$ NMR showed a deshielded signal at $11.73 \mathrm{ppm}$ for $\mathrm{NH}$ function while olefinic proton was resonated at $\delta 6.7 \mathrm{ppm}$ due to the electronic effect of $\mathrm{C}=\mathrm{O}$ also the $\mathrm{CH}_{2} \mathrm{CH}_{3}$ was detected at the expected $\delta$ and multiplicity. Mass spectrum showed a peak at $\mathrm{m} / \mathrm{z} 342.39\left(\mathrm{M}^{+}, 6.08 \%\right)$ cross ponding to its molecular ion with a base peak at $\mathrm{m} / \mathrm{z} 115.97(100 \%)$.

The cyclization of thiourea unit of compound $\mathbf{3}$ was performed via the initial formation of bis compound $\mathbf{6}$ followed by intramolecular triazine cyclization via losing of ethanol (Scheme 3). 
<smiles>C=CCOC(=O)NC(=S)N(C(=S)NC(=O)OCC)C(=S)N(C(=O)OCC)C(=S)NC(=O)OCCC</smiles>

8

Scheme 3

The triazine cyclization was potentiated by spectral data which revealed a medium sharp peak at $3188 \mathrm{~cm}^{-1}, \mathrm{C}=\mathrm{O}$ absorption frequency at 1724 $\mathrm{cm}^{-1}$ in addition to $\mathrm{C}=\mathrm{S}$ band at $1252 \mathrm{~cm}^{-1}$. The triazine structure was also proved by ${ }^{1} \mathrm{H}$ NMR that showed down field signals of $\mathrm{SH}$; $\mathrm{NH}$ at $\delta 13.05$ ppm and $11.72 \mathrm{ppm}$, the aliphatic $\mathrm{CH}_{2} \mathrm{CH}_{3}$ was located at $4.2 \mathrm{ppm}$ and $1.24 \mathrm{ppm}$ as a quartet and triplet respectively. ${ }^{13} \mathrm{C}$ was also in an agreement with the assigned symmetric structure, thus signals at $171 ; 172 \mathrm{ppm}$ was observed for $\mathrm{SP}^{2}$ carbon of $\mathrm{C}=\mathrm{O}$ and $153.4 \mathrm{ppm}$ for $\mathrm{SP}^{2}$ carbon of $\mathrm{C}=\mathrm{S}$ while the $\mathrm{SP}^{3}$ carbon showed absorption signals at $62.46 \mathrm{ppm}, 14.06$ ppm respectively.

Benzoylation of thiosemicarbazide 3 using benzoyl chloride 9 resulted in triazole cyclization to furnish triazole derivative $\mathbf{1 1}$ via the initial acyclic compound 10 followed by heterocyclization, [hydrolysis and decarboxylation], subsequent dehydration (Scheme 4).

The triazole skeleton 11 was proved from analytical and spectral data. Which show absorption frequency at $3385 \mathrm{~cm}^{-1}, 1635 \mathrm{~cm}^{-1}, 1602 \mathrm{~cm}^{-1}$ and $1338 \mathrm{~cm}^{-1}$ for $\mathrm{NH}, \mathrm{C}=\mathrm{O}, \mathrm{C}=\mathrm{N}$ and $\mathrm{C}=\mathrm{S}$ functions respectively. Also, ${ }^{1} \mathrm{HNMR}$ showed abroad signal at $11.73 \mathrm{ppm}$ for NH's, and the deshielded aromatic proton was appeared in region $8.3-6.2 \mathrm{ppm}$ together with the aliphatic protons that resonated up field region. ${ }^{13} \mathrm{C}$ of the same compound resonated at 172.02, 162.32, 156.3 and $153.84 \mathrm{ppm}$ for $\mathrm{SP}^{2}$ carbon of $\mathrm{C}=\mathrm{O}, 2 \mathrm{C}=\mathrm{S}, \mathrm{C}=\mathrm{N}$ in addition to aromatic $\mathrm{SP}^{2}$ carbon and aliphatic $\mathrm{SP}^{3}$ carbon. 


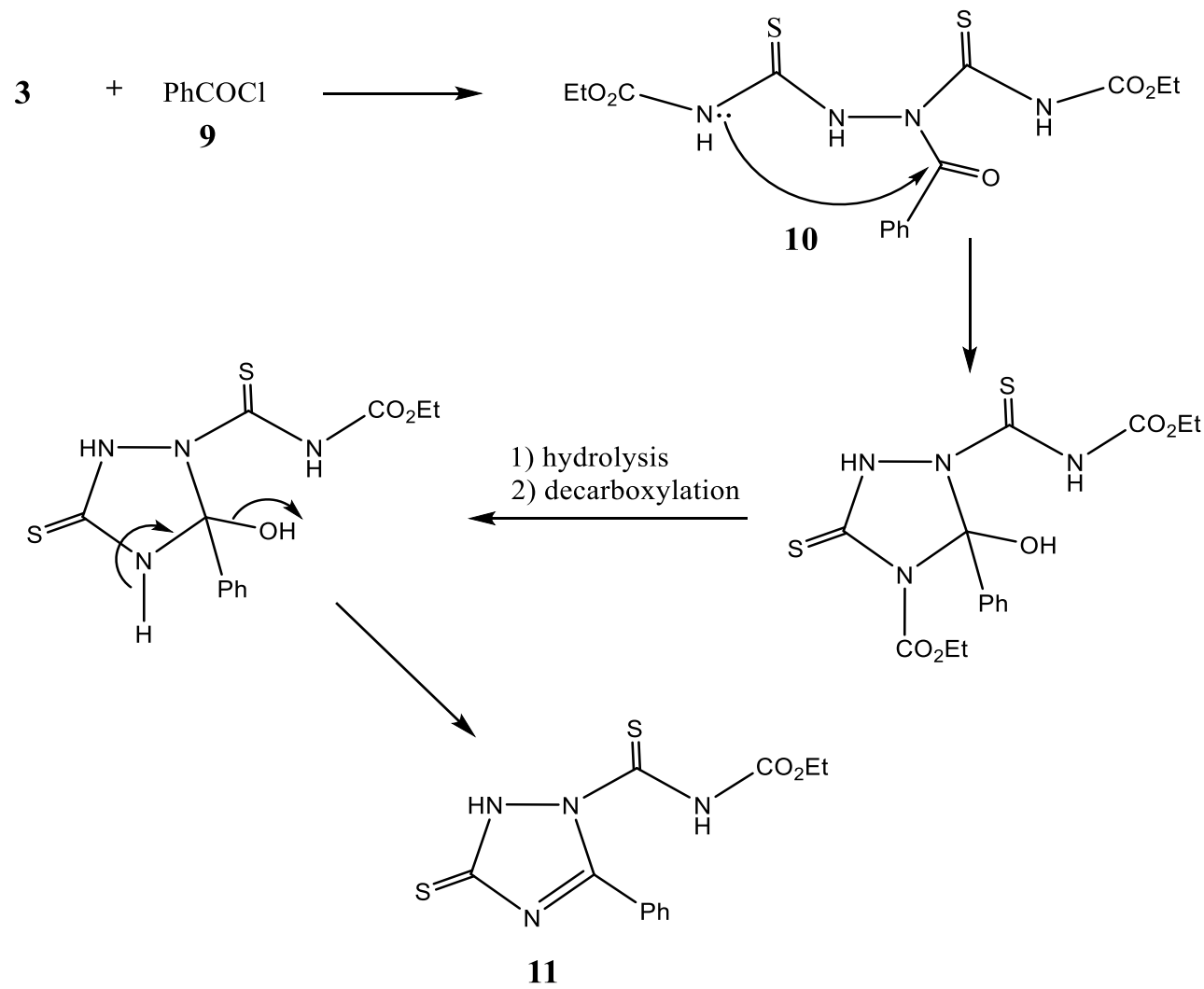

Scheme 4

A one pot three component reaction of compound $\mathbf{3}$ and maleic anhydride 12 resulted in Michael addition, intramolecular thiadiazine cyclization to produce furothiadiazine as afinal product $\mathbf{1 3}$ (Scheme 5).<smiles>CCCCCCOC(=O)NC(=S)NNC(=S)NC(=O)OCC</smiles><smiles>CCOC(=O)/N=C1\NN(C(=S)NC(=O)OCC)C2=C(CC(=O)O2)S\C1=N\C(=O)OCC</smiles> 
The spectral data of furothiadiazine $\mathbf{1 3}$ showed absorption frequencies at $3142 \mathrm{~cm}^{-1}, 1726 \mathrm{~cm}^{-1}, 1712 \mathrm{~cm}-1$ for $\mathrm{NH}$ and $2 \mathrm{CO}$ functions respectively. Also ${ }^{1} \mathrm{H}$ NMR potentiated the assigned structure 13, thus abroad signal

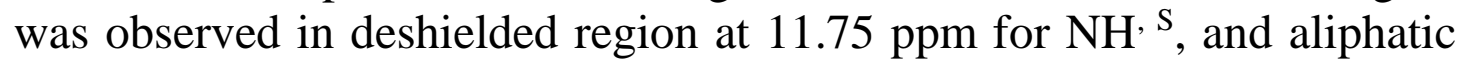
protons for $\mathrm{CH}_{2} \mathrm{CH}_{3}$ structure in addition to doublet of $\mathrm{CH}_{2}$ at $2.8 \mathrm{ppm}$. ${ }^{13} \mathrm{C}$ revealed signals at $162.31 \mathrm{ppm}, 156.3 \mathrm{ppm}$ and $153.84 \mathrm{ppm}$ for $\mathrm{SP}^{2}$ carbon of $\mathrm{C}=\mathrm{O}, \mathrm{C}=\mathrm{S}$ and $\mathrm{C}=\mathrm{N}$ in addition to $\mathrm{SP}^{3}$ carbon signals that located at $61.96 \mathrm{ppm}, 53.04 \mathrm{ppm}$, and $14.29 \mathrm{ppm}$.

As depicted in scheme (6), cyclohexanopyrimidinthione 16 was obtained from cyclocondensation of two equivalent of cyclohexanone 14 with thiosemicarbazide $\mathbf{3}$, that form non isolable cyclic enamine $\mathbf{1 5}$ followed by the pyrimidine cyclization via the attack of cyclic enaminic nucleophilic carbon to the electrophilic ester carbonyl carbon.<smiles>CCCOC(=O)NC(=S)NNC(=S)NC(=O)OCC</smiles><smiles>CCOC(=O)NC(=S)N(C1=CCCCC1)C1CCCCC1N(C1=CCCCC1)C1=CCCCC1</smiles>

Scheme 6

The spectral data of the condensed skeleton $\mathbf{1 6}$ was in agreement with assigned structure, so IR spectrum showed $\mathrm{OH}, \mathrm{C}=\mathrm{S}$ frequency at $v 3180$ $\mathrm{cm}^{-1}, v 1227 \mathrm{~cm}^{-1}$ respectively. Also ${ }^{1} \mathrm{H}$ NMR potentiated of the structure, so $\mathrm{OH}$ signal was observed at $\delta 7.94 \mathrm{ppm}$ in addition to cyclohexane protons that located in up field position. ${ }^{13} \mathrm{C}$ showed $\mathrm{SP}^{2}$ carbons at $\delta$ $162.29 \mathrm{ppm}, 156.29 \mathrm{ppm}$ and $153.83 \mathrm{ppm}$ while $\mathrm{SP}^{3}$ carbons were located at $61.95 \mathrm{ppm}, 35.76 \mathrm{ppm}, 30.75 \mathrm{ppm}$ and $14.29 \mathrm{ppm}$.

Triazole formation was achieved by keeping of thiosemicarbazide deriveative 3 and ammonium isothiocyanate 17 under thermal condition via initial formation of non-isolable compound $\mathbf{1 8}$ that loss $2 \mathrm{H}_{2} \mathrm{~S}$ (Scheme 7). 
<smiles>CCOC(=O)NC(=S)NNC(=S)NC(=O)OCC</smiles>

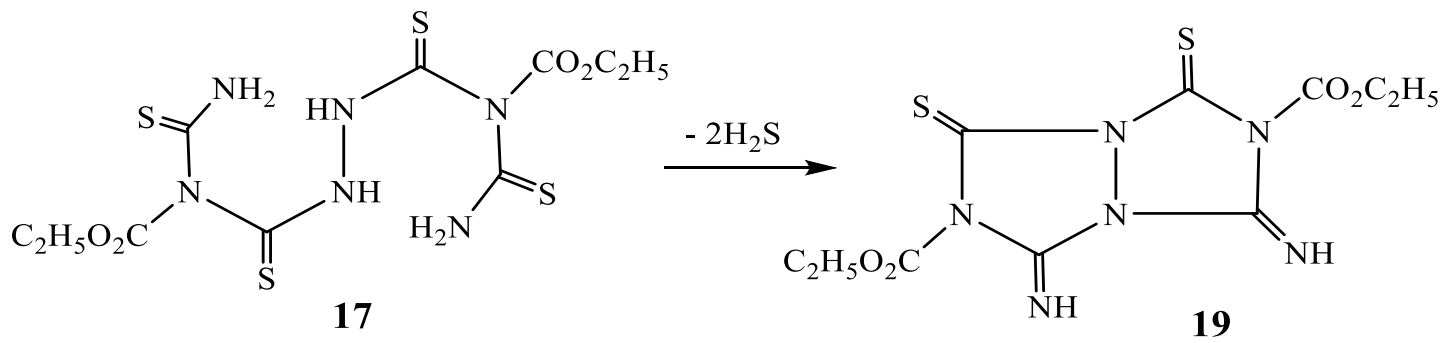

Scheme 7

Compound 19 showed absorption bands at $3355 \mathrm{~cm}^{-1}, 1726 \mathrm{~cm}^{-1}$ and $1235 \mathrm{~cm}^{-1}$ for $\mathrm{NH}, \mathrm{C}=\mathrm{O}$ and $\mathrm{C}=\mathrm{S}$. ${ }^{1} \mathrm{HNMR}$ spectrum of compound 19 revealed signals at $11.73 \mathrm{ppm}$ for $\mathrm{NH}$ proton also the quartet and triplet for $\mathrm{CH}_{3} \mathrm{CH}_{2}-$ structure was observed at $4.197 \mathrm{ppm}$ and $1.24 \mathrm{ppm}$ respectively. Mass spectrum showed a peak at $\mathrm{m} / \mathrm{z} 408.48\left(\mathrm{M}^{+}, 6 \%\right)$ a corresponding to its molecular ion with a base peak at $\mathrm{m} / \mathrm{z} 85.07(100 \%)$. Base induced alkylation of thiosemicarbazide derivative $\mathbf{3}$ using ethyl bromoacetate $\mathbf{2 0}$ followed by the attack of nucleophilic carbonion to the ester electrophilic carbonyl carbon finished the thiazole derivative $\mathbf{2 2}$ (Scheme 8).<smiles>CCOC(=O)NC(=S)NNC(=S)NC(=O)OCC</smiles>

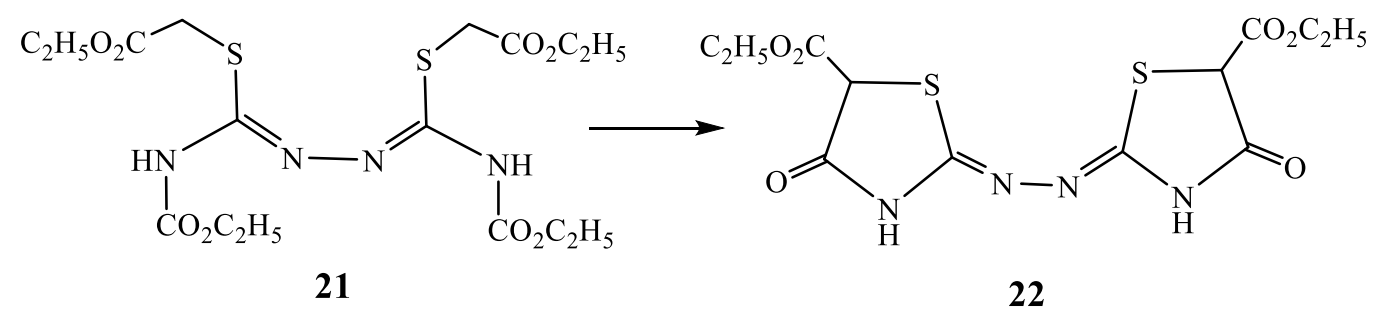


The chemical structure of synthesized thiazole derivative $\mathbf{2 2}$ was elucidated by analysis of its spectroscopic data. In IR spectrum of compound $\mathbf{2 2}$ there are absorption bands at $3144 \mathrm{~cm}^{-1}$ and $\left(1728-1710 \mathrm{~cm}^{-1}\right)$ for $\mathrm{NH}$ and $\mathrm{C}=\mathrm{O}$ respectively. Its ${ }^{1} \mathrm{H}$ NMR displayed a deshielded band at $\delta$ $11.73 \mathrm{ppm}$ for $\mathrm{NH}^{\mathrm{S}}$ the ester group and methenyl protons were located at expected $\delta$ and multiplicity. Mass spectrum showed a peak at $\mathrm{m} / \mathrm{z} 374.04$ $\left(\mathrm{M}^{+}, 51.76 \%\right)$ corresponding to its molecular ion with a base peak at $\mathrm{m} / \mathrm{z}$ 291.12(100\%).

[2+3] cyclocondensation of acetylacetone $\mathbf{2 3}$ and thiosemicarbazide derivative 3 provided pyrazole cyclization 25 via initial formation of enaminic system 24 followed by the attack of nucleophilic enaminic carbon to thioxo electrophilic carbon and subsequent loss of $\mathrm{H}_{2} \mathrm{~S}$ (Scheme 9).<smiles>CCOC(=O)NC(=S)NNC(=S)NC(=O)OCC</smiles>

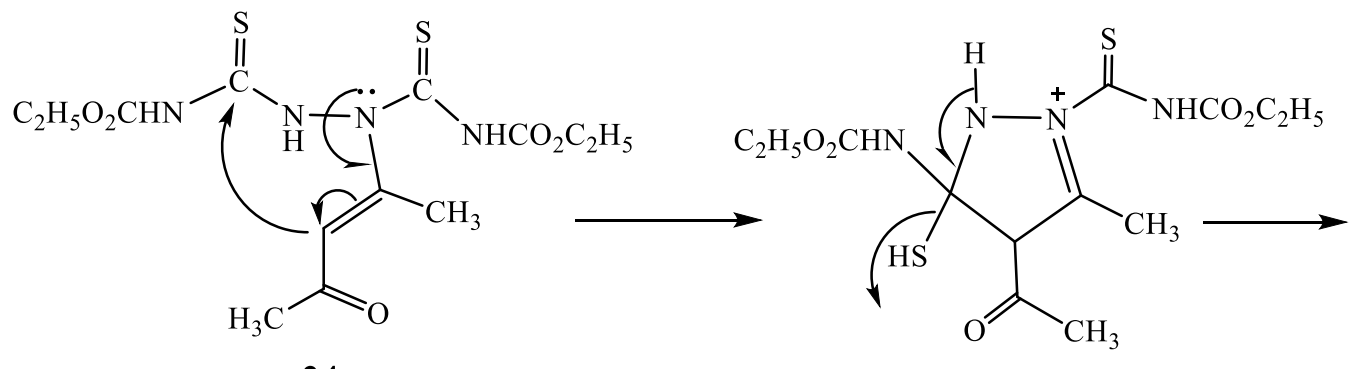

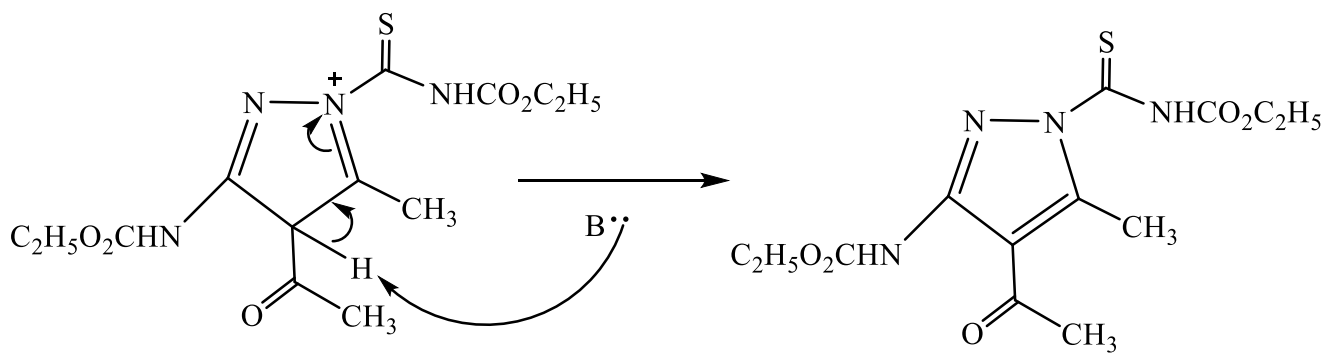

Scheme 9

The pyrazole structure $\mathbf{2 5}$ was confirmed by spectroscopic analysis. IR spectrum showed $\mathrm{NH}$ stretching frequency at $3140 \mathrm{~cm}^{-1}$ and $\mathrm{C}=\mathrm{O}$ functions at $1724 \mathrm{~cm}^{-1}$ and $1712 \mathrm{~cm}^{-1} .{ }^{1} \mathrm{H}$ NMR spectrum of compound 
25 showed signal at $\delta 11.68 \mathrm{ppm}$ for $\mathrm{NH}, \mathrm{NH}$ of different electronic environment at $\delta 7.94 \mathrm{ppm}$, quarteteat $\delta 4.20$, two methyl groups at $\delta 2.94$ ppm and $\delta 2.88 \mathrm{ppm}$ while the triplet at $\delta 1.24 \mathrm{ppm}$ for ester $\mathrm{CH}_{3} \cdot{ }^{13} \mathrm{C}$ showed $\mathrm{SP}^{2}$ carbons at $\delta 162.33 \mathrm{ppm}, 156.32 \mathrm{ppm}$ and $153.85 \mathrm{ppm}$ while $\mathrm{SP}^{3}$ carbons were located at $61.98 \mathrm{ppm}, 35.80 \mathrm{ppm}, 30.78$ and $14.31 \mathrm{ppm}$.

Formalin 26 and thiosemicarbazide 3 undergo thermal triazolotriazole cyclization as shown in (Scheme 10).<smiles>CCOC(=O)NC(=S)NNC(=S)NC(=O)OCC</smiles>
3<smiles>CCCCCCCCCOC(=O)N1CN2C(=S)N(C(=O)OCC)CN2C1=S</smiles>

\section{Scheme 10}

The structure of desired triazolotriazole 27 was elucidated from spectroscopic data. IR spectrum showed $\mathrm{C}=\mathrm{O}, \mathrm{C}=\mathrm{S}$ frequency at $1710 \mathrm{~cm}^{-1}$, $1226 \mathrm{~cm}^{-1}$ respectively. Also ${ }^{1} \mathrm{H}$ NMR showed quartet at $\delta 4.19 \mathrm{ppm}$ for $\mathrm{C}_{2} \mathrm{CH}_{3}$, singlet at $\delta 3.74 \mathrm{ppm}$ for $-\mathrm{NCH}_{2} \mathrm{~N}$ - while $\mathrm{C}_{3} \mathrm{CH}_{2}$ was observed as triplet at $\delta 1.24 \mathrm{ppm}$. Mass spectrum showed a peak at $\mathrm{m} / \mathrm{z} 318.37$ $\left(\mathrm{M}^{+}, 27.89 \%\right)$ corresponding to its molecular ion with a base peak at $\mathrm{m} / \mathrm{z}$ 63.86(100\%).

Thiosemicarbazide $\mathbf{3}$ suffers intramolecular base mediated cyclization affording triazole derivative $\mathbf{2 8}$ (Scheme 11).

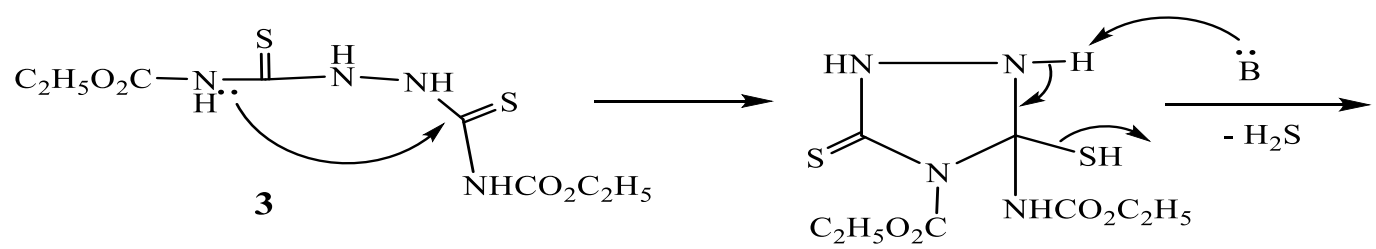<smiles>CCOC(=O)n1c(NC(=O)CC)n[nH]c1=S</smiles>

Scheme 11 
The title compound was proved by analytical and spectral data, thus IR spectrum showed vibrational stretching band at $3150 \mathrm{~cm}^{-1}, 1649 \mathrm{~cm}^{-1}$ and $1228 \mathrm{~cm}^{-1}$ for $\mathrm{NH}, \mathrm{C}=\mathrm{O}$ and $\mathrm{C}=\mathrm{S}$ function. ${ }^{1} \mathrm{H}$ NMR revealed broad signal at $\delta 11.66 \mathrm{ppm}$ for cyclic $\mathrm{NH}$ while exocyclic $\mathrm{NH}$ was observed at $\delta 7.94 \mathrm{ppm}$ in addition to $\mathrm{CH}_{2} \mathrm{CH}_{3}$ signals which observed at the expected $\delta$ and multiplicity. Mass spectrum showed a peak at $\mathrm{m} / \mathrm{z} 260\left(\mathrm{M}^{+}, 6.01 \%\right)$ corresponding to its molecular ion with a base peak at $\mathrm{m} / \mathrm{z} 59.99(100 \%)$. Keeping thiosemicarbazide $\mathbf{3}$ and propinaldehyde 29 under reflux provided triazolotriazole $\mathbf{3 1}$ as showen in (scheme 12).
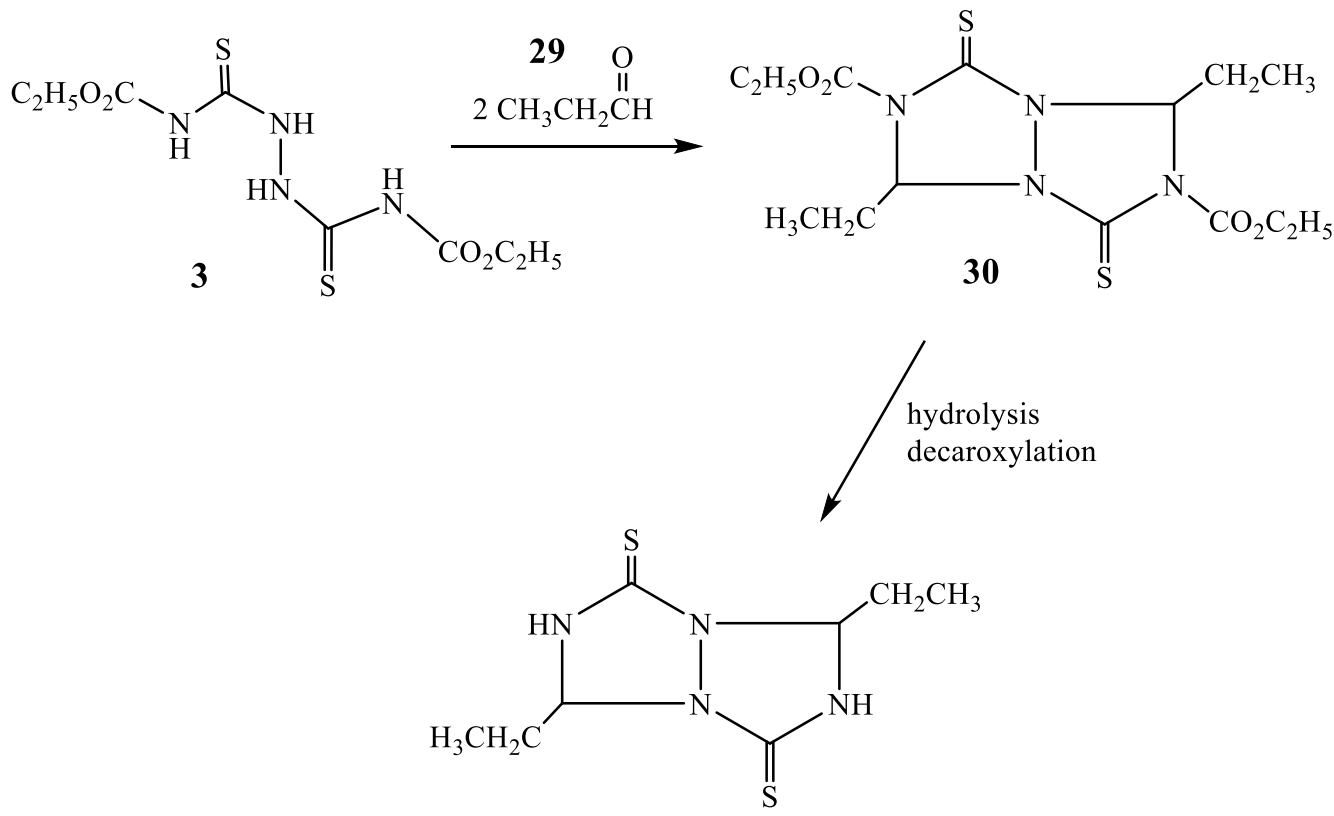

31

Scheme 12

The structure of triazolotriazole $\mathbf{3 1}$ was elucidated from spectroscopic data. IR spectrum showed $\mathrm{NH}, \mathrm{C}=\mathrm{S}$ frequency at $3140 \mathrm{~cm}^{-1}, 1236 \mathrm{~cm}^{-1}$ respectively. Also ${ }^{1} \mathrm{H}$ NMR showed $\delta 11.73 \mathrm{ppm}$ for $\mathrm{NH}$, quartet at $\delta$ $4.20 \mathrm{ppm}$ for $\mathrm{CH}_{2} \mathrm{CH}_{3}$, while $\underline{\mathrm{CH}}_{3} \mathrm{CH}_{2}$ was observed as a triplet at $\delta 1.24$ ppm. Mass spectrum showed a peak at $\mathrm{m} / \mathrm{z} 230.40\left(\mathrm{M}^{+}, 2.43 \%\right)$ corresponding to its molecular ion with a base peak at $\mathrm{m} / \mathrm{z} 59.97(100 \%)$.

Oxidative intramolecular cyclization of thiosemicarbazide $\mathbf{3}$ to oxadiazole 32 was achieved by the effect of iodine (scheme 13). 
<smiles>CCOC(=O)NC(=S)NNC(=S)NC(=O)OCC</smiles>

3

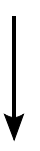<smiles>CCOC1NC2=[SH]C(OCC)NC(=S)N2O1</smiles>

32

Scheme 13

The structure of compound $\mathbf{3 2}$ was elucidated from spectroscopic data. IR spectrum showed $\mathrm{NH}, \mathrm{C}=\mathrm{S}$ frequency at $3140 \mathrm{~cm}^{-1}, 1230 \mathrm{~cm}^{-1}$ respectively. Also ${ }^{1} \mathrm{H}$ NMR showed $\delta 11.72 \mathrm{ppm}$ for $-\mathrm{CO}-\mathrm{NH}-\mathrm{CS}-, \delta 7.94$ ppm for $-\mathrm{CS}-\mathrm{NH}-\mathrm{N}-$ and the $\mathrm{CH}_{2} \mathrm{CH}_{3}$ was detected at the expected $\delta$ and multiplicity. ${ }^{13} \mathrm{C}$ was in an agreement with the assigned symmetric structure, thus signals at $170.83 \mathrm{ppm}$ was observed for $\mathrm{SP}^{2}$ carbon of $\mathrm{C}=\mathrm{O}$ and $156.28 \mathrm{ppm}, 153.81 \mathrm{ppm}$ for $\mathrm{SP}^{2}$ carbon of $2 \mathrm{C}=\mathrm{S}$ while the $\mathrm{SP}^{3}$ carbon showed absorption signals at $62.45 \mathrm{ppm}, 14.29 \mathrm{ppm}$ respectively.

Cyclization of thiosemicarbazide derivative $\mathbf{3}$ to triazolthione $\mathbf{3 4}$ was achieved by acylation using succinic acid, cyclization, hydrolysis and subsequent dehydration (scheme 14).

The spectral data of the triazolthione skeleton $\mathbf{3 4}$ was in agreement with assigned structure, so IR spectrum showed $\mathrm{NH}$ at $3138 \mathrm{~cm}^{-1}, 2 \mathrm{C}=\mathrm{O}$ at $1726 \mathrm{~cm}^{-1}, 1710 \mathrm{~cm}^{-1}$ and $\mathrm{C}=\mathrm{S}$ at $1236 \mathrm{~cm}^{-1}$. Also ${ }^{1} \mathrm{H}$ NMR potentiated of the structure, so $\mathrm{COOH}$ signal was observed at $\delta 12.19 \mathrm{ppm}, \mathrm{NH}$ at $\delta 11.8$ ppm, quartet at $\delta 4.21 \mathrm{ppm}$ for $\underline{\mathrm{CH}}_{2} \mathrm{CH}_{3}$, while $\underline{\mathrm{C}}_{3} \mathrm{CH}_{2}$ was observed as a triplet at $\delta 1.24$.

\section{Experimental}

Melting points were measured using an Electro thermal IA 9100 apparatus with open capillary tube and are uncorrected. All experiments were carried out using drying solvents. Products were purified by crystallization. The IR spectra ( $\mathrm{KBr}$ disc) were recorded on a PyeUnicam Sp-3-300 or a Shimadzu FT-IR 8101 PC infrared spectrophotometer. The ${ }^{1} \mathrm{H}$ NMR and ${ }^{13} \mathrm{C}$ NMR spectra were measured on a JEOL-JNM-LA $400 \mathrm{MHz}$ spectrometer using DMSO- $\mathrm{d}_{6}$ as a solvent. 
<smiles>CCCCOC(=O)NC(=S)NNC(=S)NC(=O)OCC</smiles>
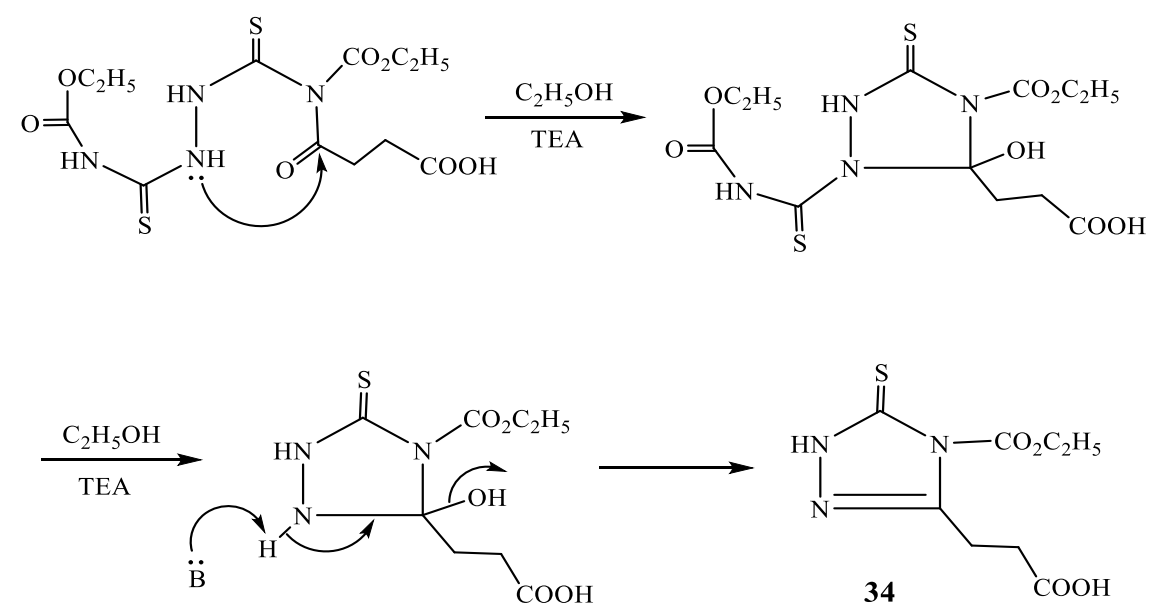

Scheme 14

All chemical shifts were expressed on the $\delta$ (ppm) scale using TMS as an internal standard reference. The coupling constant $(J)$ values are given in $H z$. Mass spectra were measured on a GCMS-QP1000 EX spectrometer at $70 \mathrm{Ev}$. Analytical data were obtained from the Microanalysis Center at Cairo University, Giza, Egypt.

Ethyl (2-((((2 $\lambda^{3}$-ethynyl)- $\lambda^{7}$-oxidanyl) carbonyl) carbamothioyl)hydrazine-1-carbonothioyl) carbamate (3)

A mixture of ammonium thiocyanate $(0.04 \mathrm{~mol})$ in dry aceton $(60 \mathrm{~mL})$ was warmed till complete dissolving then ethyl chloroformate $(0.04 \mathrm{~mol})$ was added dropwise and stirring in flask for $1 \mathrm{~h}$, after that hydrazine hydrate $(0.04 \mathrm{~mol})$ was added drop wise and stirring for $1 \mathrm{~h}$. The reaction mixture was poured into $\mathrm{H}_{2} \mathrm{O}$. The formed product was filtered off, dried and crystallized from ethanol (95\%) to give compound $\mathbf{3}$ in $90 \%$ yield as pale yellow powder. Mp. $285-287{ }^{\circ} \mathrm{C}$, IR $\left(\mathrm{KBr}, \mathrm{cm}^{-1}\right): 3184(\mathrm{NH}), 1724$ $(\mathrm{C}=\mathrm{O}), 1212(\mathrm{C}=\mathrm{S}) ;{ }^{1} \mathrm{H}$ NMR $\left(400 \mathrm{MHz}, \mathrm{DMSO}-\mathrm{d}_{6}\right) \delta(\mathrm{ppm}): 1.24(\mathrm{t}$, $6 \mathrm{H}, \underline{2 \mathrm{CH}_{3}} \mathrm{CH}_{2}, \mathrm{~J}=6.4 \mathrm{~Hz}$ ), $4.2\left(\mathrm{q}, 4 \mathrm{H}, \underline{2 \mathrm{CH}_{2}} \mathrm{CH}_{3}, \mathrm{~J}=7.2 \mathrm{~Hz}\right.$ ), 11.7 (s, $2 \mathrm{H}, 2 \mathrm{NH}), 13.05$ (s, 2H, NH-NH); Mass: $\mathrm{m} / \mathrm{z}=\mathrm{M}^{+} 294(68.67 \%)$ and 157 (100\%); Anal. Calcd for $\mathrm{C}_{8} \mathrm{H}_{14} \mathrm{~N}_{4} \mathrm{O}_{4} \mathrm{~S}_{2}$ (294.34): $\mathrm{C}, 32.64 ; \mathrm{H}, 4.79 ; \mathrm{N}$, 19.03. Found: C, 32.58; H, 4.74; N, $19.05 \%$. 


\section{Diethyl 2,2'-(3,7-dithioxotetrahydro-1H,5H-[1,2,4] triazolo[1,2-a] $[1,2,4]$ triazole-1,5-diylidene)(2E,2E')-diacetate (5)}

A mixture of compound $3(0.005 \mathrm{~mol})$, diethylmalonate $(0.005 \mathrm{~mol})$ and few drops of triethylamine in ethanol absolute $(20 \mathrm{~mL})$ was heated under reflux for $6 \mathrm{~h}$. The reaction mixture was cooled at room temperat-ure and poured into $\mathrm{HCl} / \mathrm{H}_{2} \mathrm{O}$ (1:10). The product was filtered off, washed with water and crystallized from ethanol to give compound $\mathbf{5}$ in $75 \%$ yields as white powder. Mp. over $360{ }^{\circ} \mathrm{C}$, IR $\left(\mathrm{KBr}, \mathrm{cm}^{-1}\right): 3140(\mathrm{NH}), 1711(\mathrm{C}=\mathrm{O})$, 1581 $(\mathrm{C}=\mathrm{C}), 1235(\mathrm{C}=\mathrm{S}) ;{ }^{1} \mathrm{H}$ NMR $\left(400 \mathrm{MHz}, \mathrm{DMSO}-\mathrm{d}_{6}\right) \delta(\mathrm{ppm}): 1.24$

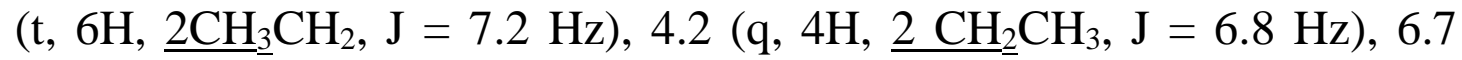
(s,2H, olefinic proton), $11.7(\mathrm{~s}, 2 \mathrm{H}, 2 \mathrm{NH}) ;$ Mass: $\mathrm{m} / \mathrm{z}=\mathrm{M}^{+} 342(6.08 \%)$ and 115 (100\%); Anal. Calcd for $\mathrm{C}_{12} \mathrm{H}_{14}-\mathrm{N}_{4} \mathrm{O}_{4} \mathrm{~S}_{2}$ (342.39): C, 42.10; H, 4.12; N, 16.36. Found: $\mathrm{C}, 42.12 ; \mathrm{H}, 4.10 ; \mathrm{N}, 16.34 \%$.

Diethyl 4',6-dimercapto-4,6'-dioxo-2,2'-dithioxo-2H,2' H-[1,1'-bi(1,3,5triazine)]-3,3'(4H,6'H)-dicarboxylate $(8)$

A mixture of ammonium thiocyanate $(0.005 \mathrm{~mol})$ in dry aceton $(50 \mathrm{~mL})$ was warmed till complete dissolving then ethyl chloroformate $(0.005$ mol) was added drop wise and stirring in flask for $1 \mathrm{~h}$, after that compound $3(0.005 \mathrm{~mol})$ was added and few drops of triethylamine, then refluxed for $2 \mathrm{hr}$. The reaction mixture was cooled and poured into $\mathrm{HCl} / \mathrm{H}_{2} \mathrm{O}$ (1:10). The product was filtered off, washed with water and crystallized from ethanol to give compound 7 in $85 \%$ yields as yellow powder. Mp. over $360^{\circ} \mathrm{C}$, IR $\left(\mathrm{KBr}, \mathrm{cm}^{-1}\right)$ : $3188(\mathrm{NH}), 1724(\mathrm{C}=\mathrm{O}), 1213(\mathrm{C}=\mathrm{S}) ;{ }^{1} \mathrm{H}$ NMR (400 MHz, DMSO-d d $) \delta(\mathrm{ppm}): 1.24\left(\mathrm{t}, 6 \mathrm{H}, \underline{2 \mathrm{CH}_{3}} \mathrm{CH}_{2}, \mathrm{~J}=7.2 \mathrm{~Hz}\right.$ ), $4.2\left(\mathrm{q}, 4 \mathrm{H}, 2 \mathrm{CH}_{2} \mathrm{CH}_{3}, \mathrm{~J}=7.2 \mathrm{~Hz}\right), 11.7$ (s, $\left.2 \mathrm{H}, 2 \mathrm{NH}\right), 13.05$ (s, 2H, 2SH); ${ }^{13} \mathrm{C}-\mathrm{NMR}: \delta=14.06\left(\mathrm{CH}_{3}\right), 62.46\left(\mathrm{CH}_{2}\right), 153.45(\mathrm{C}=\mathrm{S}), 170.84$, 171.85(C=O); Anal. Calcd for $\mathrm{C}_{12} \mathrm{H}_{12} \mathrm{~N}_{6} \mathrm{O}_{6} \mathrm{~S}_{4}$ (464.5): $\mathrm{C}, 31.03 ; \mathrm{H}, 2.60$; N, 18.09. Found: C, 31.01; H, 2.50; N, 18.07\%.

Ethyl (5-phenyl-3-thioxo-2,3-dihydro-1H-1,2,4-triazole-1-carbonothioyl) carbamate (11)

A mixture of compound 3 (0.005 mol) and benzoyl chloride $(0.005 \mathrm{~mol})$ in ethanol absolute $(50 \mathrm{~mL})$ was heated under reflux for $6 \mathrm{~h}$. The reaction mixture was cooled at room temperature and poured into water. The product was filtered off, washed with water and crystallized from methanol and DMF to give compound $\mathbf{1 1}$ in $75 \%$ yields as yellow powder. Mp. over $360^{\circ} \mathrm{C}$, IR $\left(\mathrm{KBr}, \mathrm{cm}^{-1}\right): 3385(\mathrm{NH}), 1635(\mathrm{C}=\mathrm{O}), 1602$ $(\mathrm{C}=\mathrm{N}), 1338(\mathrm{C}=\mathrm{S}) ;{ }^{1} \mathrm{H}$ NMR $\left(400 \mathrm{MHz}, \mathrm{DMSO}-\mathrm{d}_{6}\right) \delta(\mathrm{ppm}): 1.24(\mathrm{t}$, $\left.3 \mathrm{H}, \mathrm{CH}_{3} \mathrm{CH}_{2}, \mathrm{~J}=6.8 \mathrm{~Hz}\right), 4.2\left(\mathrm{q}, 2 \mathrm{H}, \mathrm{CH}_{2} \mathrm{CH}_{3}, \mathrm{~J}=6.8 \mathrm{~Hz}\right), 6.2-8.3(\mathrm{~m}$, 5H, ArH's), 11.73 (br.s, H, NH's); ${ }^{13} \mathrm{C}-\mathrm{NMR}: \delta=14.30,21.05\left(\mathrm{CH}_{3}\right)$, 
$61.96\left(\mathrm{CH}_{2} \mathrm{O}\right) 153.84(\mathrm{C}=\mathrm{N}), 156.30,162.32(2 \mathrm{C}=\mathrm{S}), 172.02(\mathrm{C}=\mathrm{O})$; Anal. Calcd for $\mathrm{C}_{12} \mathrm{H}_{12} \mathrm{~N}_{4} \mathrm{O}_{2} \mathrm{~S}_{2}$ (308.37): C, 46.74; H, 3.92; N, 18.17 . Found: C, 46.72; H, 3.89; N, 18.15\%.

Ethyl (z)-(1-((ethoxycarbonyl)carbamothioyl)-6-oxo- 1,2,5, 6-tetrahydro-3H-furo[2,3-e][1,2,4] thiadiazin-3-ylidene)carbamate (13)

A mixture of compound 3 (0.005 mol), maleic anhydride $(0.005 \mathrm{~mol})$ and few drops of triethylamine in ethanol absolute $(30 \mathrm{~mL})$ was heated under reflux for $6 \mathrm{~h}$. The reaction mixture was cooled at room temperature and poured into $\mathrm{HCl} / \mathrm{H}_{2} \mathrm{O}(1: 10)$. The product was filtered off, washed with water and crystallized from methanol and DMF to give compound $\mathbf{1 3}$ in $80 \%$ yields as yellow powder. Mp. over $360^{\circ} \mathrm{C}$, IR $\left(\mathrm{KBr}, \mathrm{cm}^{-1}\right): 3142$ $(\mathrm{NH}), 1726$ and $1712(2 \mathrm{C}=\mathrm{O}), 1581(\mathrm{C}=\mathrm{C}), 1541(\mathrm{C}=\mathrm{N}), 1236(\mathrm{C}=\mathrm{S})$; ${ }^{1} \mathrm{H}$ NMR (400 MHz, DMSO-d $\left.{ }_{6}\right) \delta(\mathrm{ppm}): 1.24\left(\mathrm{t}, 6 \mathrm{H}, \mathrm{CH}_{3} \mathrm{CH}_{2}, \mathrm{~J}=6.8\right.$ $\mathrm{Hz}$ ), 4.2 (q, $4 \mathrm{H}, 2 \mathrm{CH}_{2} \mathrm{CH}_{3}, \mathrm{~J}=6.8 \mathrm{~Hz}$ ), 11.7 (br.s, $\mathrm{H}, \mathrm{NH}$ ) ${ }^{13} \mathrm{C}-\mathrm{NMR}: \delta=$ $14.29,30.78\left(2 \mathrm{CH}_{3}\right), 53.04,61.96\left(2 \mathrm{CH}_{2}\right), 153.84,156.30$ and 162.31 $(\mathrm{C}=\mathrm{N}, \mathrm{C}=\mathrm{S}$ and $\mathrm{C}=\mathrm{O})$; Anal. Calcd for $\mathrm{C}_{12} \mathrm{H}_{14} \mathrm{~N}_{4} \mathrm{O}_{6} \mathrm{~S}_{2}$ (374.39): $\mathrm{C}$, $38.50 ; \mathrm{H}, 3.77$; N, 14.9. Found: C, 38.45; H, 3.72; N, $14.8 \%$.

Diethyl (1,2-di(cyclohex-1-en-1-yl)hydrazine-1,2-dicarbonothioyl) dicarbamate (16)

A mixture of compound $3(0.005 \mathrm{~mol})$, cyclohexanone $(0.005 \mathrm{~mol})$ and few drops of triethylamine in ethanol absolute $(50 \mathrm{~mL})$ was heated under reflux for $4 \mathrm{~h}$. The reaction mixture was cooled at room tempera-ture and poured into $\mathrm{HCl} / \mathrm{H}_{2} \mathrm{O}(1: 10)$. The product was filtered off, washed with water and crystallized from methanol and DMF to give compound $\mathbf{1 6}$ in $85 \%$ yields as pale brown powder. Mp. over $360^{\circ} \mathrm{C}$, IR $\left(\mathrm{KBr}, \mathrm{cm}^{-1}\right): 3180$ $(\mathrm{OH}), 1226(\mathrm{C}=\mathrm{S}) ;{ }^{1} \mathrm{H}$ NMR (400 MHz, DMSO-d $\left.{ }_{6}\right) \delta(\mathrm{ppm}): 2.88(\mathrm{~m}$, $8 \mathrm{H}, 4 \mathrm{CH}_{2}$ cyclohexane), $7.94(\mathrm{~s}, 2 \mathrm{H}, \mathrm{OH}) ;{ }^{13} \mathrm{C}-\mathrm{NMR}: \delta=14.29,30.75$ and $35.76\left(3 \mathrm{CH}_{3}\right), 61.95\left(\mathrm{CH}_{2}\right), 153.83,156.29$ and $162.29(\mathrm{C}=\mathrm{N}$ and $2 \mathrm{C}=\mathrm{S}$ ); Anal. Calcd for $\mathrm{C}_{16} \mathrm{H}_{18} \mathrm{~N}_{4} \mathrm{O}_{2} \mathrm{~S}_{2}$ (362.47): C, 53.02; H, 5.01; N, 15.46. Found: C, 53.01; H, 4.98; N, $15.43 \%$.

Diethyl 2,2'-(hydrazine-1,2-dicarbonothioyl)bis(2-carbamothioyl hydrazine-1-carboxylate) (19)

Ammonium thiocyanate $(0.005 \mathrm{~mol})$ in acetic acid $(50 \mathrm{~mL})$ was warmed till complete dissolving then compound $\mathbf{3}$ was added and ref-luxed for 4 $\mathrm{h}$. The reaction mixture was cooled at room temperature and poured into water. The product was filtered off, washed with water and crystallized from methanol to give compound $\mathbf{1 9}$ in $63 \%$ yields as white powder. Mp. over $360{ }^{\circ} \mathrm{C}$, IR $\left(\mathrm{KBr}, \mathrm{cm}^{-1}\right): 3355(\mathrm{NH}), 1726$ and1710 $(2 \mathrm{C}=\mathrm{O})$, 
1235(C=S); ${ }^{1} \mathrm{H}$ NMR (400 MHz, DMSO-d $\left.{ }_{6}\right) \delta(\mathrm{ppm}): 1.24(\mathrm{t}, 6 \mathrm{H}$, $\underline{2 \mathrm{CH}_{3}} \mathrm{CH}_{2}, \mathrm{~J}=7.2 \mathrm{~Hz}$ ), $4.2\left(\mathrm{q}, 4 \mathrm{H}, \underline{2 \mathrm{CH}_{2}} \mathrm{CH}_{3}, \mathrm{~J}=7.2 \mathrm{~Hz}\right), 11.73(\mathrm{~s}, 2 \mathrm{H}$, 2NH); Mass: $\mathrm{m} / \mathrm{z}=\mathrm{M}^{+} 408(6.01 \%)$ and 85(100\%); Anal. Calcd for $\mathrm{C}_{10} \mathrm{H}_{12} \mathrm{~N}_{6} \mathrm{O}_{4} \mathrm{~S}_{4}$ (408.48): C, 29.40; H, 2.96; N, 20.57. Found: C, 29.37; H, 2.94; N, $20.53 \%$.

\section{Diethyl 2,2'-(hydrazine-1,2-diylidene)(2Z,2'Z)-bis(4-oxothiazolidine- 5-carboxylate) (22)}

A mixture of compound $3(0.005 \mathrm{~mol})$, ethyl bromoacetate $(0.005 \mathrm{~mol})$ and few drops of triethylamine in ethanol absolute $(40 \mathrm{~mL})$ was heated under reflux for $4 \mathrm{~h}$. The reaction mixture was cooled at room temperature and poured into $\mathrm{HCl} / \mathrm{H}_{2} \mathrm{O}(1: 10)$. The product was filtered off, washed with water and crystallized from methanol to give compound 22 in $83 \%$ yields as white powder. Mp. over $360^{\circ} \mathrm{C}$, IR $\left(\mathrm{KBr}, \mathrm{cm}^{-1}\right): 3144$ $(\mathrm{NH}), 1728$ and $1710(\mathrm{C}=\mathrm{O}) ;{ }^{1} \mathrm{H}$ NMR $\left(400 \mathrm{MHz}, \mathrm{DMSO}-\mathrm{d}_{6}\right) \delta(\mathrm{ppm})$ : $1.24\left(\mathrm{t}, 6 \mathrm{H}, \underline{2 \mathrm{CH}_{3}} \mathrm{CH}_{2}, \mathrm{~J}=6.8 \mathrm{~Hz}\right), 4.2\left(\mathrm{q}, 4 \mathrm{H}, \underline{2 \mathrm{CH}_{2}} \mathrm{CH}_{3}, \mathrm{~J}=7.2 \mathrm{~Hz}\right)$, 11.73 (s, 2H, 2NH); Mass: $\mathrm{m} / \mathrm{z}=\mathrm{M}^{+} 374(51.76 \%)$ and $291(100 \%)$; Anal. Calcd for $\mathrm{C}_{12} \mathrm{H}_{14} \mathrm{~N}_{4} \mathrm{O}_{6} \mathrm{~S}_{2}$ (374.39): C, 38.50; H, 3.77; N, 14.97. Found: C, 38.47; H, 3.75; N, 14.96\%.

\section{Ethyl (4-acetyl-1-((ethoxycarbonyl)carbamothioyl)-5-methyl-1H-pyr- azol-3-yl)carbamate (25)}

A mixture of compound $3(0.005 \mathrm{~mol})$, acetyl acetone $(0.005 \mathrm{~mol})$ and few drops of triethylamine in ethanol absolute $(50 \mathrm{~mL})$ was heated under reflux for $6 \mathrm{~h}$. The reaction mixture was cooled at room temper-ature and poured into $\mathrm{HCl} / \mathrm{H}_{2} \mathrm{O}$ (1:10). The product was filtered off, washed with water and crystallized from methanol and DMF give compound 25 in $79 \%$ yields as yellow brown powder. Mp. over $360{ }^{\circ} \mathrm{C}$, IR $\left(\mathrm{KBr}, \mathrm{cm}^{-1}\right)$ : $3140(\mathrm{NH}), 1724$ and $1712(\mathrm{C}=\mathrm{O}), 1230(\mathrm{C}=\mathrm{S}) ;{ }^{1} \mathrm{H}$ NMR $(400 \mathrm{MHz}$, DMSO-d $\left.{ }_{6}\right) \delta(\mathrm{ppm}): 1.24\left(\mathrm{t}, 6 \mathrm{H}, \underline{2 \mathrm{CH}_{3}} \mathrm{CH}_{2}, \mathrm{~J}=6.8 \mathrm{~Hz}\right), 2.88$ and $2.94(\mathrm{~s}$, $\left.6 \mathrm{H}, 2 \mathrm{CH}_{3}\right), 4.2\left(\mathrm{q}, 4 \mathrm{H}, 2 \mathrm{CH}_{2} \mathrm{CH}_{3}, \mathrm{~J}=6.8 \mathrm{~Hz}\right), 7.94(\mathrm{~s}, 2 \mathrm{H}, 2 \mathrm{NH}$ aliphatic), 11.68 (br.s, $\mathrm{H}, \mathrm{NH}$ ); ${ }^{13} \mathrm{C}-\mathrm{NMR}: \delta=14.31,30.78$ and 35.80 $\left(4 \mathrm{CH}_{3}\right), 61.98\left(2 \mathrm{CH}_{2}\right), 153.85,156.32$ and $162.33(\mathrm{C}=\mathrm{S}$ and $2 \mathrm{C}=\mathrm{O})$; Anal. Calcd for $\mathrm{C}_{13} \mathrm{H}_{18} \mathrm{~N}_{4} \mathrm{O}_{5} \mathrm{~S}$ (342.37): C, 45.61; H, 5.30; N, 16.36. Found: C, 45.58; H, 5.28; N, $16.33 \%$.

\section{Diethyl 1,5-dithioxo-1H,5H-[1,2,4]triazolo[1,2-a][1,2,4] triazole-2,6 $(3 \mathrm{H}, 7 \mathrm{H})$-dicarboxylate $(27)$}

A mixture of compound 3 (0.005 mol), formalin $(40 \%, 3 \mathrm{ml})$ and few drops of triethylamine in ethanol absolute $(40 \mathrm{~mL})$ was heated under reflux for $4 \mathrm{~h}$. The reaction mixture was cooled at room temperature and 
poured into $\mathrm{HCl} / \mathrm{H}_{2} \mathrm{O}(1: 10)$. The product was filtered off, washed with water and crystallized from methanol and DMF to give compound 27 in $80 \%$ yields as pale orange powder. Mp. over $360{ }^{\circ} \mathrm{C}$, IR $\left(\mathrm{KBr}, \mathrm{cm}^{-1}\right)$ : $1710(\mathrm{C}=\mathrm{O}), 1226(\mathrm{C}=\mathrm{S}) ;{ }^{1} \mathrm{H}$ NMR $\left(400 \mathrm{MHz}, \mathrm{DMSO}-\mathrm{d}_{6}\right) \delta: 1.24(\mathrm{t}, 6 \mathrm{H}$, $\left.\underline{2 \mathrm{CH}_{3}} \mathrm{CH}_{2}, \mathrm{~J}=7.2 \mathrm{~Hz}\right), 3.74\left(\mathrm{~s}, 2 \mathrm{H},-\mathrm{NCH}_{2} \mathrm{~N}-\right), 4.2\left(\mathrm{q}, 4 \mathrm{H}, \underline{2 \mathrm{CH}_{2}} \mathrm{CH}_{3}, \mathrm{~J}=\right.$ $6.8 \mathrm{~Hz}$ ); Mass: $\mathrm{m} / \mathrm{z}=\mathrm{M}^{+} 318(27.89 \%)$ and $63(100 \%)$; Anal. Calcd for $\mathrm{C}_{10} \mathrm{H}_{14} \mathrm{~N}_{4} \mathrm{O}_{4} \mathrm{~S}_{2}$ (318.37): C, 37.73; H, 4.43; N, 17.60. Found: C, 37.71; H, $4.42 ; \mathrm{N}, 17.57 \%$.

\section{Ethyl 3-((ethoxycarbonyl)amino)-5-thioxo-1,5-dihydro-4H-1,2,4-tria- zole-4-carboxylate (28)}

A mixture of compound $\mathbf{3}(0.005 \mathrm{~mol})$ and few drops of triethyl-amine in ethanol absolute $(50 \mathrm{~mL})$ was heated under reflux for $4 \mathrm{~h}$. The reaction mixture was cooled at room temperature and poured into $\mathrm{HCl} / \mathrm{H}_{2} \mathrm{O}(1: 10)$. The product was filtered off, washed with water and crystallized from methanol to give compound $\mathbf{2 8}$ in $\mathbf{7 0 \%}$ yields as pale brown powder. Mp. over $360{ }^{\circ} \mathrm{C}$, IR $\left(\mathrm{KBr}, \mathrm{cm}^{-1}\right)$ : $3140(\mathrm{NH}), 1649(\mathrm{C}=\mathrm{O}), 1228(\mathrm{C}=\mathrm{S}) ;{ }^{1} \mathrm{H}$ NMR (400 MHz, DMSO-d $)_{6} \delta(\mathrm{ppm}): 1.24\left(\mathrm{t}, 6 \mathrm{H}, \underline{2 \mathrm{CH}_{3}} \mathrm{CH}_{2}, \mathrm{~J}=7.2 \mathrm{~Hz}\right.$ ), 4.2 (q, $4 \mathrm{H}, \underline{2 \mathrm{CH}_{2}} \mathrm{CH}_{3}, \mathrm{~J}=6.8 \mathrm{~Hz}$ ), 7.94 (s, H, exocyclic $\mathrm{NH}$ ), 11.66 (br.s, $\mathrm{H}$, cyclic $\mathrm{NH}) ;$ Mass: $\mathrm{m} / \mathrm{z}=\mathrm{M}^{+} 260(8.71 \%)$ and $59(100 \%)$; Anal. Calcd for $\mathrm{C}_{8} \mathrm{H}_{12} \mathrm{~N}_{4} \mathrm{O}_{4} \mathrm{~S}$ (260.27): C, 36.92; H, 4.65; N, 21.53. Found: C, 36.89; $\mathrm{H}, 4.63 ; \mathrm{N}, 21.51 \%$.

\section{3,7-Diethyl-1H,5H-[1,2,4]triazolo[1,2-a][1,2,4]triazole-1,5-dithione} (31)

A mixture of compound $3(0.005 \mathrm{~mol})$, propinaldehyde $(0.005 \mathrm{~mol})$ and few drops of triethylamine in ethanol absolute $(50 \mathrm{~mL})$ was heated under reflux for $4 \mathrm{~h}$. The reaction mixture was cooled at room temper-ature and poured into $\mathrm{HCl} / \mathrm{H}_{2} \mathrm{O}$ (1:10). The product was filtered off, washed with water and crystallized from methanol and DMF to give compound $\mathbf{3 1}$ in $90 \%$ yields white yellow powder. Mp. over $360^{\circ} \mathrm{C}$, IR $\left(\mathrm{KBr}, \mathrm{cm}^{-1}\right): 3140$ $(\mathrm{NH}), 1236(\mathrm{C}=\mathrm{S}) ;{ }^{1} \mathrm{H}$ NMR (400 MHz, DMSO-d $)_{6} \delta: 1.24(\mathrm{t}, 6 \mathrm{H}$, $\left.\underline{2 \mathrm{CH}_{3}} \mathrm{CH}_{2}, \mathrm{~J}=6.8 \mathrm{~Hz}\right), 4.2\left(\mathrm{q}, 4 \mathrm{H}, \underline{2 \mathrm{CH}_{2}} \mathrm{CH}_{3}, \mathrm{~J}=7.2 \mathrm{~Hz}\right), 11.73(\mathrm{~s}, 2 \mathrm{H}$, 2NH); Mass: $\mathrm{m} / \mathrm{z}=\mathrm{M}^{+} 230(2.43 \%)$ and 59 (100\%); Anal. Calcd for $\mathrm{C}_{8} \mathrm{H}_{14} \mathrm{~N}_{4} \mathrm{~S}_{2}$ (230.35): C, 41.71; H, 6.13; N, 24.32. Found: C, 41.73; H, $6.11 ; \mathrm{N}, 24.30 \%$.

\section{5,5'-Diethoxy-[2,2'-bi(1,2,4-oxadiazolidine)]-3,3'-dithione (32)}

A mixture of compound $3(0.005 \mathrm{~mol})$ and iodine $(30 \%, 5 \mathrm{ml})$ in ethanol absolute $(50 \mathrm{~mL})$ was heated under reflux for $4 \mathrm{~h}$. The reaction mixture was cooled at room temperature and poured into water. The pro-duct was 
filtered off, washed with water and crystallized from methanol and DMF give compound 32 in70\% yields as brown powder. Mp. over $360{ }^{\circ} \mathrm{C}$, IR $\left(\mathrm{KBr}, \mathrm{cm}^{-1}\right): 3140(\mathrm{NH}), 1230(\mathrm{C}=\mathrm{S}) ;{ }^{1} \mathrm{H}$ NMR (400 MHz, DMSO-d 6 ) $\delta$ (ppm): $1.24\left(\mathrm{t}, 6 \mathrm{H}, 2 \mathrm{CH}_{3} \mathrm{CH}_{2}, \mathrm{~J}=2.4 \mathrm{~Hz}\right), 2.72$ and $2.88(\mathrm{~s}, 2 \mathrm{H}, 2 \mathrm{CH}$ cyclic), 4.2 (q, $4 \mathrm{H}, \underline{2 \mathrm{CH}_{2}} \mathrm{CH}_{3}, \mathrm{~J}=6.8 \mathrm{~Hz}$ ), 11.72 (br.s, $2 \mathrm{H}, 2 \mathrm{NH}$ ); ${ }^{13} \mathrm{C}-$ NMR: $\delta=14.06$ and $14.29\left(2 \mathrm{CH}_{3}\right), 61.94$ and $62.45\left(2 \mathrm{CH}_{2}\right), 153.45$, 153.81, 156.28 and $170.83(2 \mathrm{C}=\mathrm{N}$ and $2 \mathrm{C}=\mathrm{S})$; Anal. Calcd for $\mathrm{C}_{8} \mathrm{H}_{14} \mathrm{~N}_{4} \mathrm{O}_{4} \mathrm{~S}_{2}$ (294.34): C, 32.64; H, 4.79; N, 19.03. Found: C, 32.61; H, $4.75 ; \mathrm{N}, 19.01 \%$.

\section{3-(4-(Ethoxycarbonyl)-5-thioxo-4,5-dihydro-1H-1,2,4-triazol-3-yl) propanoic acid (34)}

A mixture of compound $3(0.005 \mathrm{~mol})$, succinic acid $(0.005 \mathrm{~mol})$ and few drops of triethylamine in toluene $(50 \mathrm{~mL})$ was heated under reflux for $6 \mathrm{~h}$. The reaction mixture was cooled at room temperature and poured into $\mathrm{HCl} / \mathrm{H}_{2} \mathrm{O}(1: 10)$. The product was filtered off, washed with water and crystallized from methanol to give compound $\mathbf{3 4}$ in $80 \%$ yields pale brown powder. Mp. over $360{ }^{\circ} \mathrm{C}$, IR $\left(\mathrm{KBr}, \mathrm{cm}^{-1}\right)$ : $3138(\mathrm{NH}), 1726$ and $1710(2 \mathrm{C}=\mathrm{O}), 1236(\mathrm{C}=\mathrm{S}) ;{ }^{1} \mathrm{H}$ NMR $\left(400 \mathrm{MHz}, \mathrm{DMSO}-\mathrm{d}_{6}\right) \delta: 1.24(\mathrm{t}$, $\left.3 \mathrm{H}, \underline{\mathrm{CH}}_{3} \mathrm{CH}_{2}, \mathrm{~J}=6.8 \mathrm{~Hz}\right), 2.65\left(\mathrm{~m}, 4 \mathrm{H}, \underline{2 \mathrm{CH}_{2}} \mathrm{CH}_{2}, \mathrm{~J}=6 \mathrm{~Hz}\right), 4.2(\mathrm{q}, 2 \mathrm{H}$, $\underline{\mathrm{CH}_{2}} \mathrm{CH}_{3}, \mathrm{~J}=7.2 \mathrm{~Hz}$ ), 11.8 (br.s, H, NH), 12.19 (br.s, H, COOH); Anal. Calcd for $\mathrm{C}_{8} \mathrm{H}_{11} \mathrm{~N}_{3} \mathrm{O}_{4} \mathrm{~S}$ (245.25): C, 39.18; H, 4.52; N, 17.13. Found: C, $39.15 ; \mathrm{H}, 4.43 ; \mathrm{N}, 17.16 \%$.

\section{References}

Avanzo R. E., Anesini C., Fascio M. L., Errea M. I. and DiAccorso N. B.; 1,2,4-Triazole d-ribose derivatives: Design, Synthesis and antitumoral evalution. Eur. J. Med. Chem., 47, 104, (2012).

Bamsal R. and Bhagchandani G.; Synthesis 2-amino-5-aroyl-1,3,4Oxadiazoles. J. Indian Chem. Soc., LIX, 277, (1982).

Bayrak H., Demirbas A., Alpay Karaoglu S. and Demirbas N.; Synthesis of some new 1,2,4-triazoles, their Mannich and Schiff bases and evaluation of their antimicrobial activities. Eur. J. Med. Chem., 44, 1057, (2009).

Chimenti F., Fioravanti R., Bolasco A., Manna F., Chimenti P., et al.; Selective inhibitory activity against MAO and molecular modeling studies of 2-thiazolylhydrazone derivatives. J. Med. Chem., 50, 707712 (2007).

Dobosz M., Wujec M. and Pitucha M.; Cyclization of 1-\{[(4-Methyl4H-1,2,4-triazol-3-yl)sulfanyl]acetyl thiosemicarbazides to1,2,4- 
Triazole and 1,3,4-Thiadiazole Derivatives and their pharmacological properties. Ann. Univ. Maria Curie-Sklod-owska, Lublin, Chem., 50/51, 67, (1995/1996).

Foroumadi A., Mansouri S., Kiani Z. and Rahmani A.; Synthesis and in vitro antibacterial evaluation of $\mathrm{N}$-[5-(5-nitro-2-thienyl)-1,3,4thiadi-azole-2-yl]piperazinyl quinolones. Eur. J. Med. Chem., 38, 851-854, (2003).

Ghoneim A. A. and Assy M. G.; Synthesis and Characterization of Antimicrobial Activity of Azoles and Azines Derivatives from Tertiary Butyl Carbazatel. Organic Chem. Curr. Res., 4, 3, (2015).

Greenbaum D. C.,Mackey Z., Hansell E., Doyle P., Gut J., Caffrey C. R., Lehrman J., Rosenthal P. J., McKerrow J. H. and Chibale K.; Synthesis and Structure-Activity Relationships of parasiticidal thiosemi-cabazone. J. Med. Chem., 47, 3212, (2004).

Karakus S. and Rollas S.; Synthesis and antituberculosis activity of new N-Phemyl-N'-[4-(5-alkyl/arylamino-1,3,4-thiadiazole-2-yl)Phenyl]thioureas. Farmaco, 57, 577, (2002).

Noguchi T., Hasegawa M., Tomisawa K. and Mitsukuchi M.; Synthesis and structure-activity relationships of 5phenylthiophenecar-boxylic acid derivatives as antirheumatic agents. Bioorg. Med. Chem., 11, 4729-4742, (2003).

Sancak K., Ünver Y. and Er M.; Synthesis of 2-Acylamino, 2-Aroylamino and Ethoxycarbonyl Imino-1,3,4-thiadiazoles as Antitumor Agents. Turk. J. Chem., 31, 125, (2007).

Tozkoparan B., Aktay G. and Yesilada E.; Synthesis of some 1,2,4triazolo[3,2-b]-1,3-thiazine-7-ones with potential analgesic and antiinflammatory activites. Farmaco, 57, 145, (2002). 


\section{تخليق وحولقة بعض مشتقات الثيوسيميكاربازيد}

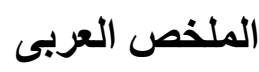

إضافة الهيدرازين الدتهترت ب إلى الهيتيروآلين ا ( الإيثيل هيدرازين كاربونوثيويلكاربامات

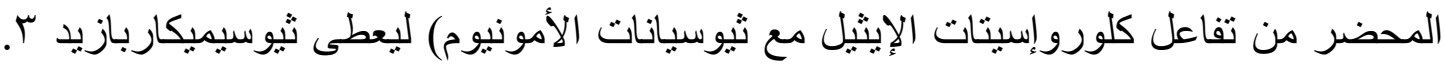

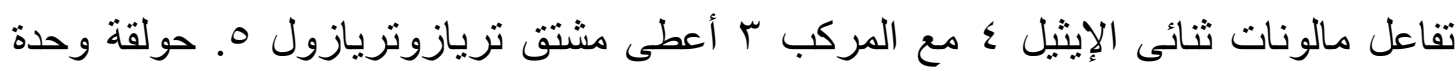

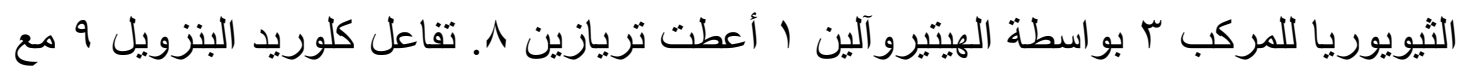

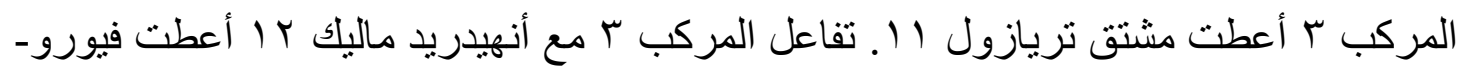
ثياديازين با. التكاثف الحلقى للاكسان الحلقى أمع المركب ب أعطت هكسانوحلقى بيريميدين-

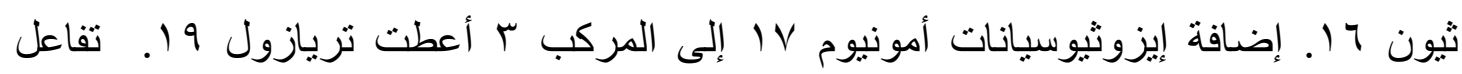
المركب r مع برومو إسيتات الإيثيل • r أعطت مشتق الثيازول r r. التكاثف الحلقى للأسيتيل

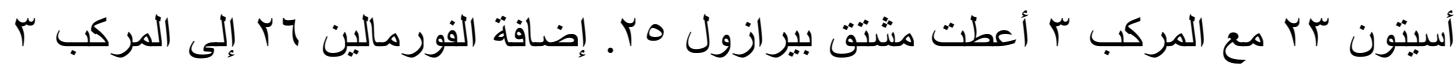

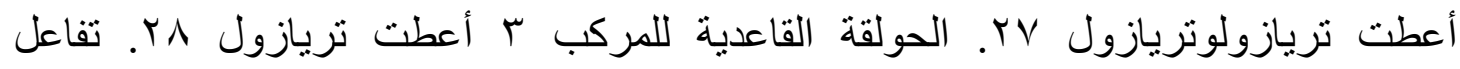

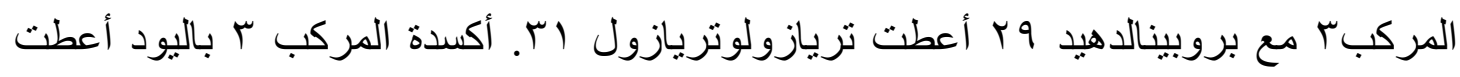

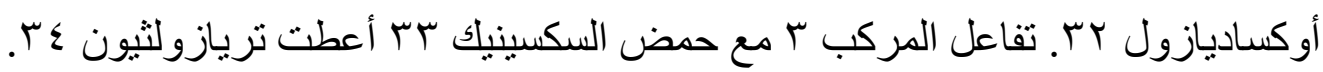

